\begin{tabular}{|c|c|c}
\hline-1 & Journal of Advances in Science and Engineering \\
\hline (JASE) & SPR \\
\hline
\end{tabular}

\title{
Prospects of the Nigeria Brewery Industry
}

\author{
*Ugboya, P. A., \& Odiamenhi, A. M. \\ Department of Industrial \& Production Engineering, Faculty of Engineering \& Tecbnology, Ambrose Alli University, Ekpoma, Nigeria \\ *Corresponding author's e-mail: upaigbe2002@yahoo.com
}

\begin{abstract}
This study analyses the economics and determinants of a brewery industry (Guinness Nigeria Limited) with a view of establishing the future of breweries in Nigeria. The specific objectives were to estimate the factors influencing products production and determine the viability of products manufactured by the company. Multiple regression and the ordinary least square techniques were used to analyse the long-term (2006 - 2015) annual time series data observed for the study. The results showed that the major determinant of Stout, Harp and Malt production is demanded. As a significant input, it positively influences product production. The observed values of regression coefficients $\left(\mathrm{R}^{2}\right)$ are 0.99349 (for Stout), 0.90981 (for Harp), and 0.99498 (for Malt), which indicates that they are reliable for determining the future of Guinness Nigeria Ltd. The results also showed that logarithm of demand for Stout production (LstoutD) of 13.5277, LharpD of 21.8439 and LmaltD of 12.2653 were projected respectively up to the year 2025, an indication that brewery production in the state is viable and that future is bright.
\end{abstract}

\section{Keywords}

Adjusted market value for inflation;

Brewery industries;

Logarithm of demand;

Logarithm of

inflation;

Multiple regression analysis;

Ordinary least square.

Received 30 Jan. 2019; Revised 6 Apr. 2019; Accepted 16 Apr. 2019; Available online 30 Apr. 2019.

Copyright (C) 2019 The Authors. This is an open access article under the CC BY-NC-ND license (http://creativecommons.org/licenses/by-nc-nd/4.0/)

\section{Introduction}

Manufacturing is an important activity to promote economic growth and development. In most modern economies, manufacturing sector serves as the vehicle for the production of goods and services, the generation of employment and the enhancement of incomes. The manufacturing sector plays a catalytic role in a modern economy and has many benefits crucial for economic transformation. Hence, manufacturing industry has been accepted as a major driving force of the modern economy. Kayode (2009) described industry and in particular the manufacturing sub-sector, as the heart of the economy. Nations that export manufactured products tend to generate higher marginal GDP growth, which supports higher incomes and marginal tax revenue needed to fund the quality of life initiatives such as health care and infrastructure in the economy. The field is an important source for engineering job opportunities. Among developed countries, it is an important source of well-paying jobs for the middle class to facilitate greater social mobility for successive generations on the economy.

In the light of the above, Nigeria has employed several strategies, which were aimed at enhancing productivity of the sector in order to bring about economic growth and development. For instance, the country adopted the import substitution industrialisation strategy during the First National Development Plan (1962-1968) aimed at reducing the volume of imports of finished goods and encouraging foreign exchange savings by producing locally some of the imported consumer goods (CBN, 2003). The country consolidated her import substitution industrialisation strategy during the Second National Development Plan period (1970-74), which actually fell within the oil boom era. At that time, manufacturing activities were so organised to depend on imported inputs because of the weak technological base of the economy. However, as a result of the collapse of the world oil market in the early 1980s, there was a severe reduction in the earnings from oil exports. Consequently, the import-dependent industrial structure that had emerged became unsustainable owing to the paucity of earnings from oil exports, which could not adequately pay for the huge import bills. Various policy measures were adopted to ameliorate the above situation, such as the stabilisation measures of 1982 and the restrictive monetary policy and stringent exchange control

Article citation: Ugboya, P. A., \& Odiamenhi, A. M. (2019). Prospects of the Nigeria Brewery Industry. Journal of Advances in Science and Engineering, 2(1): 17-24. Retrieved from https://www.sciengtexopen.org/index.php/jase/article/view/43 
measures of 1984, all proved abortive. This led to the introduction of the Structural Adjustment Programme (SAP) in 1986 (CBN, 2003).

One of the main reasons for the introduction of SAP was to reduce the high dependence of the economy on crude oil as the major foreign earner, by promoting non-oil exports, particularly manufactured goods. But the contribution of the manufacturing sub-sector GDP has declined steadily, due to a number of factors. As a result, government introduced many other economic policies. Despite these efforts of the government, the performance of the manufacturing sectors is still not clear. The brewery industry has contributed much to the growth and development of Nigerian economy. Ola (2011) noted that this sector contributes about 28 percent of Manufactured Value Added (MVA) and provides direct employment for over 30,000 persons. The indirect employment associated with the industry is close to 300,000 including the firms producing ancillary services. The banning of the importation of barley by the federal government of Nigeria in 1987 and 1988 encouraged local farmers and agricultural research institutes in the country to massively produce substitute grains like sorghum, maize etc., to satisfy the needs of the brewery industry. This indeed enhanced the economic power of farmers, and further increased employment.

The above economic benefit of the brewery industry can only be sustained when the brewery firms make profit, which ensures their remaining in business. The continuous shutting down of brewery firms because of high cost of inputs hinders the economic growth and development of the nation. Equity Research Report (2006) opined that the main threats to the firms in the industry include rising cost of petroleum products and cost of raw materials such as barley (imported with high excise costs). The ban on the importation of barley and the replacement of barley malt with local substitutes have further increased the input cost of beer production. Packaging rates are higher, storage and transportation costs have increased drastically. Yin (2003) noted that wage rate rose relative to both capital and material prices until 1980. Thereafter, wages fell relative to capital but continued to rise relative to material prices.

Guinness Nigeria PLC is a foremost brewery company in Nigeria and leader in the manufacturing sector of the economy. It is truly a successful company with a rich heritage and great track record of growth and strong performance. Guinness Nigeria is not only regarded as an ironic African Company but renowned internationally for its brand of unmatched quality. The aim of this paper is to study the determinants and economics of products manufactured by Guinness Nigeria PLC in Edo state. The specific objectives are to (1) estimate the factors influencing products production in the state; (2) determine the viability of products manufactured by the company and (3) forecast the output of products up to year 2025.

\subsection{Beer Manufacturing Process}

Brewing is the production of beer by steeping a starch source (commonly cereal grains, the most popular of which is barley) in water and fermenting the resulting sweet liquid with yeast (Evans, 2001). It may be done in a brewery by a commercial brewer, at home by a home brewer, or by a variety of traditional methods such as communally by the indigenous peoples in Brazil when making cauim (Chris, 2013). Brewing has taken place since around the $6^{\text {th }}$ millennium $\mathrm{BC}$, and archaeological evidence suggests emerging civilisations including ancient Egypt and Mesopotamia brewed beer (Louis \& Oppenheim, 2001). Since the nineteenth century the brewing industry has been part of most western economies. Descriptions of various beer recipes can be found in cuneiform (the oldest known writing) from ancient Mesopotamia (Max, 2005). In Mesopotamia the brewer's craft was the only profession which derived social sanction and divine protection from female deities/goddesses, specifically: Ninkasi, covered the production of beer; Siris, was used in metonymic way to refer to beer, and Siduri, covered the enjoyment of beer (Louis \& Oppenheim, 2001).

As almost any cereal containing certain sugars can undergo spontaneous fermentation due to wild yeasts in the air, it is possible that beer-like beverages were independently developed throughout the world soon after a tribe or culture had domesticated cereal. The basic ingredients of beer are water and a fermentable starch source such as malted barley. Most beer is fermented with a brewer's yeast and flavoured with hops. Less widely used starch sources include millet, sorghum and cassava. Secondary sources (adjuncts), such as maize (corn), rice, or sugar, may also be used, sometimes to reduce cost, or to add a feature, such as adding wheat to aid in retaining the foamy head of the beer (Ted, 2008). The proportion of each starch source in a beer recipe is collectively called the grain bill. Steps in the brewing process include malting, milling, mashing, sparging, lautering, boiling, fermenting, conditioning, filtering and packaging. These are three main fermenting methods, warm, cool and spontaneous. Fermentation may take place in an open or closed fermenting vessel; a secondary fermentation may also occur in the cask or bottle. There are several additional brewing methods, such as barrel aging, double dropping and Yorkshire Square.

Chemical tests of ancient pottery jars reveal that beer was produced as far back as about 7,000 years ago in what is today Iran discovery reveals one of the earliest known uses of fermentation and is the earliest 
evidence of brewing to date. In Mesopotamia, the oldest evidence of beer is believed to be a 6,000 years old Sumerian tablet depicting people drinking a beverage through reed straws from a communal bowl. A 3900 year old Sumerian poem honouring Ninkasi, the patron goddess of brewing, contains the oldest surviving beer recipe, describing the production of beer from barley via bread. The invention of bread and beer has been argued to be responsible for humanity's ability to develop technology and build civilization (Mirsky, 2007). The earliest chemically confirmed barley beer to date was discovered at Godin Tepe in the centra Zagros Mountains of Iran, where fragments of a jug, at least 5,000 years old was found to be coated with beerstone, a by-product of the brewing process. Beer may have been known in Neolithic Europe as far back as 5,000 years ago (Yin, 2003) and was mainly brewed on a domestic scale.

Ale produced before the Industrial Revolution continued to be made and sold on a domestic scale, although by the $7^{\text {th }}$ century AD beer was also being produced and sold by European monasteries. During the Industrial Revolution, the production of beer moved from artisanal manufacture to industrial manufacture, and domestic manufacture ceased to be significant by the end of the $19^{\text {th }}$ century. The development of hydrometers and thermometers changed brewing by allowing the brewer more control of the process, and greater knowledge of the results. Today, the brewing industry is a global business, consisting of several dominant multinational companies and many thousands of smaller producers ranging from brewpubs to regional breweries. More than 133 billion litres (35 billion gallons) are sold per yearproducing total global revenues of $\$ 294.5$ billion $(£ 147.7$ billion $)$ in 2006 .

\section{Methods}

The study was conducted in Edo state of Nigeria. The study accessed the long-term data of products manufactured by Guinness Nigeria PLC with a view of determining the viability and prospects of the brewing industry in Nigeria. The choice of study location was guided by the fact that it is one of the major locations for Guinness Nigeria Production. Tables 1 to 6 show the observed long-term data for case study.

Table 1. Volume of Production of Stout, Harp and Malt from 2006-2015

\begin{tabular}{|c|c|c|c|}
\hline \multirow{2}{*}{ Year } & \multicolumn{3}{|c|}{ Annual Production } \\
\cline { 2 - 4 } & Stout & Harp & Malt \\
\hline 2006 & 589,302 & 492,624 & 396,268 \\
\hline 2007 & 613,035 & 506,731 & 406,993 \\
\hline 2008 & 622,824 & 514,509 & 516,008 \\
\hline 2009 & 628,966 & 574,927 & 572,321 \\
\hline 2010 & 630,468 & 598,265 & 602,146 \\
\hline 2011 & 702,141 & 600,264 & 599,866 \\
\hline 2012 & 697,982 & 598,413 & 624,936 \\
\hline 2013 & 802,143 & 603,498 & 628,421 \\
\hline 2014 & 740,209 & 630,010 & 642,218 \\
\hline 2015 & 785,881 & 614,376 & 639,743 \\
\hline
\end{tabular}

Source: Guinness Nigeria PLC

Table 2. Sales Volume of Stout, Harp and Malt from 2006-2015

\begin{tabular}{|c|c|c|c|}
\hline \multirow{2}{*}{ Year } & \multicolumn{3}{|c|}{ Annual Sales } \\
\cline { 2 - 4 } & Stout & Harp & Malt \\
\hline 2006 & 486,450 & 399,392 & 285,278 \\
\hline 2007 & 512,129 & 412,102 & 302,496 \\
\hline 2008 & 502,824 & 417,277 & 420,129 \\
\hline 2009 & 505,198 & 478,231 & 473,213 \\
\hline 2010 & 526,214 & 499,639 & 497,471 \\
\hline 2011 & 572,137 & 480,296 & 520,998 \\
\hline 2012 & 575,709 & 501,235 & 520,972 \\
\hline 2013 & 669,647 & 503,874 & 522,125 \\
\hline 2014 & 611,259 & 505,629 & 536,515 \\
\hline 2015 & 654,901 & 511,980 & 533,119 \\
\hline
\end{tabular}

Source: Guinness Nigeria PLC 


\subsection{Data analysis}

The data obtained were analysed using Ordinary Least Square (OLS) estimation techniques of regression analysis and time series model. Multiple regression was used to achieve two objectives of the study. Firstly, it was employed to determine the factors influencing products production. Secondly, it was used to forecast the output of Guinness production up to 2025 (koutsoyiannis, 1977). The model specification used for this study is given as follows:

\section{Model 1}

LHarp $\mathrm{p}=\alpha_{0}+\alpha_{1} \mathrm{LHarpD}+\alpha_{2} \mathrm{LINF}+\alpha_{3} \mathrm{LexRT}+\alpha_{4} \mathrm{LRGDP}_{\mathrm{p}}+\mu$

\section{Mode1 2}

$$
\text { LStout } \mathrm{p}=\beta_{0}+\beta_{1} \text { LStoutD }+\alpha_{2} \text { LINF }+\beta_{2} \text { LINF }+\beta_{3} \text { LexRT }+\beta_{4} \text { LRGDP }
$$

Where, LStoutD is the logarithm of demand of stout, LINF is the logarithm of inflation, LexRT is the logarithm of exchange rate, LRGDP is the logarithm of adjusted market value for inflation and $\beta_{0}, \beta_{1}, \beta_{2}, \beta_{3}$, $\beta_{4}$ are constants. Similarly,

\section{Mode13}

$$
\text { LMalt } \mathrm{p}=\gamma_{0}+\gamma_{1} \mathrm{LmaltD}+\gamma_{2} \mathrm{LINF}+\gamma_{3} \mathrm{LexRT}+\gamma_{4} \mathrm{LRGDP}
$$

Where, LMalt $\mathrm{D}$ is the logarithm of demand of malt, LINF is the logarithm of inflation, LexRT is the logarithm of Exchange rate, LRGDP is the logarithm of adjusted market value for inflation, $\gamma_{0}, \gamma_{1}, \gamma_{2}, \gamma_{3}, \gamma_{4}$, are constants.

\section{Results and Discussion}

Table 3 to Table 5 show the estimation results of factors influencing Stout, Harp and Malt production respectively.

Table 3. Estimation of factors influencing Stout Production

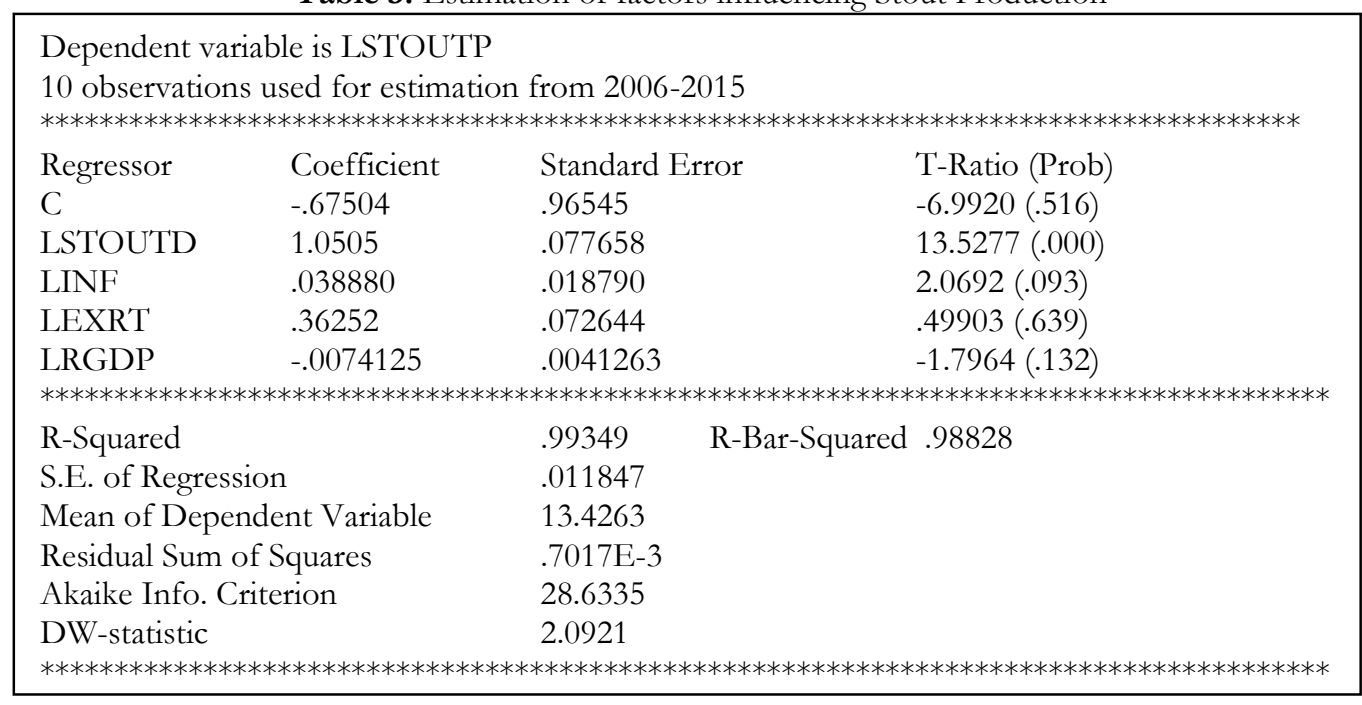

The results (from Table 3) show that stout production was influenced by demand and inflation. The demand of stout and inflation is greater than 2, which means that they influence stout production. The coefficient of determinant $\left(\mathrm{R}^{2}=0.99349\right)$, which is statistically significant shows that there is a strong relationship between the explanatory variables and the dependent variables. Dublin Watson statistics is 2.0921, which shows that there is no problem of auto-correlation and it is reliable. 
Table 4. Estimation of factors influencing Harp Production

\begin{tabular}{|c|c|c|c|}
\hline $\begin{array}{l}\text { Dependen } \\
10 \text { observa } \\
\text { ********** }\end{array}$ & $\begin{array}{l}\text { le is LHARP } \\
\text { sed for estim } \\
* * * * * * * * * * * *\end{array}$ & $\begin{array}{l}\text { form 2006-2015 } \\
* * * * * * * * * * * * * * * * * * * * * * * *\end{array}$ & $* * * * * * * * * * * * * * * *$ \\
\hline Regressor & Coefficient & Standard Error & T-Ratio (Prob) \\
\hline $\mathrm{C}$ & 2.9965 & .27600 & $10.8569(.000)$ \\
\hline LHARPD & .70946 & .032479 & $21.8439(.000)$ \\
\hline LINF & $-711 \mathrm{E}-5$ & .0023182 & $0030672(.998)$ \\
\hline LEXRT & .20133 & .034265 & $5.8757(.002)$ \\
\hline LRGDP & $-.7947 \mathrm{E}-3$ & $.7043 \mathrm{E}-3$ & $-1.1283(.132)$ \\
\hline \multicolumn{4}{|c|}{ 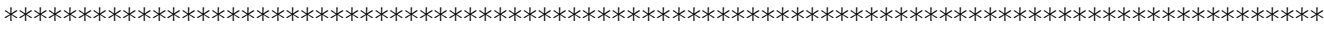 } \\
\hline R-Squared & & .90981 R-Bar-Squared & .89866 \\
\hline S.E. of Rę & & .0022502 & \\
\hline Mean of D & nt Variable & 13.2558 & \\
\hline Residual S & quares & $.5063 \mathrm{E}-5$ & \\
\hline Akaike Inf & rion & 38.7401 & \\
\hline DW-statist & & 2.0411 & \\
\hline
\end{tabular}

Table 5. Estimation of factors influencing Malt Production

\begin{tabular}{|c|c|c|c|}
\hline \multicolumn{3}{|c|}{$\begin{array}{l}10 \text { observations used for estimation form } 2006-2015 \\
* * * * * * * * * * * * * * * * * * * * * * * * * * * * * * * * * * * * * * * * * * * * * * * *\end{array}$} & $* * * * * * * * * * * * * *$ \\
\hline Regressor & Coefficient & Standard Error & T-Ratio (Prob) \\
\hline $\mathrm{C}$ & 3.4113 & .63715 & $5.3543(.003)$ \\
\hline LMALTD & .70785 & .057712 & $12.2653(.000)$ \\
\hline LINF & -.0012444 & .028005 & $-.044435(.966)$ \\
\hline LEXRT & .11832 & .11280 & $1.0490(.342)$ \\
\hline LRGDP & .0014935 & .0052403 & $.28500(.787)$ \\
\hline \multicolumn{4}{|c|}{ 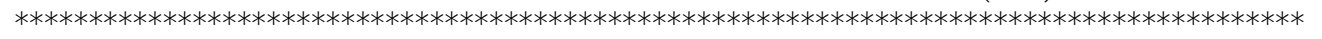 } \\
\hline \multicolumn{4}{|c|}{$\begin{array}{lll}\text { R-Squared } & .99498 & \text { R-Bar-Squared } .99096\end{array}$} \\
\hline \multicolumn{2}{|c|}{ S.E. of Regression } & .017344 & \\
\hline \multicolumn{2}{|c|}{ Mean of Dependent Variable } & 13.2268 & \\
\hline \multicolumn{2}{|c|}{ Residual Sum of Squares } & .0015041 & \\
\hline \multicolumn{2}{|c|}{ Akaike Info. Criterion } & 24.8212 & \\
\hline \multicolumn{2}{|c|}{ DW-statistic } & 2.3358 & \\
\hline
\end{tabular}

Table 4 shows that harp production was influenced by demand and exchange rate with a coefficient of determinant of 0.90981 , which is statistically significant suggests that there is a strong relationship between the explanatory table and dependent variable. Dublin Watson (DW) statistics of 2.0411 shows that there is no problem of auto-correlation and it is reliable. Similarly, the coefficient of determinant for malt production is 0.99498 , which is statistically significant indicating that there is a strong relationship between the explanatory variable and the dependent variables. The Dublin Watson statistics is 2.3358, which also shows that there is no problem to correlation and it is reliable. The general results shows that demand is higher, which means that it is the major determinant in the level of production. Tables 6 to 8 show the predicting quantity of produced Stout, Harp and Malt for the next ten years respectively while the estimated quantity is shown in Table 9. 
Table 6. Predicting Quantity of Produced Stout for the next ten years

\begin{tabular}{|c|c|c|c|}
\hline $\begin{array}{l}\text { Dependen } \\
10 \text { observa } \\
* * * * * * * * * *\end{array}$ & $\begin{array}{l}\text { ole is STOUT } \\
\text { sed for estim } \\
\text { s***********; }\end{array}$ & from $2006-2015$ & 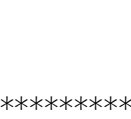 \\
\hline Regressor & Coefficient & Standard Error & T-Ratio \\
\hline $\mathrm{C}$ & 553470.3 & 20247.1 & 27.3358 \\
\hline $\mathrm{T}$ & 23240.9 & 3263.1 & 7.1223 \\
\hline$* * * * * * * * * *$ & $* * * * * * * * * * * * ;$ & $* * * * * * * * * * * * * * *$ & $* * * * * * * * *$ \\
\hline R-Squared & & -.0 .86378 & \\
\hline S.E. of Res & & -29638.7 & \\
\hline Residual S & Squares & $-7.03 e+0.9$ & \\
\hline Akaike Inf & erion & -118.0420 & \\
\hline DW-statist & & 2.2109 & \\
\hline
\end{tabular}

Table 7. Predicting Quantity of Produced Harp for the next ten years

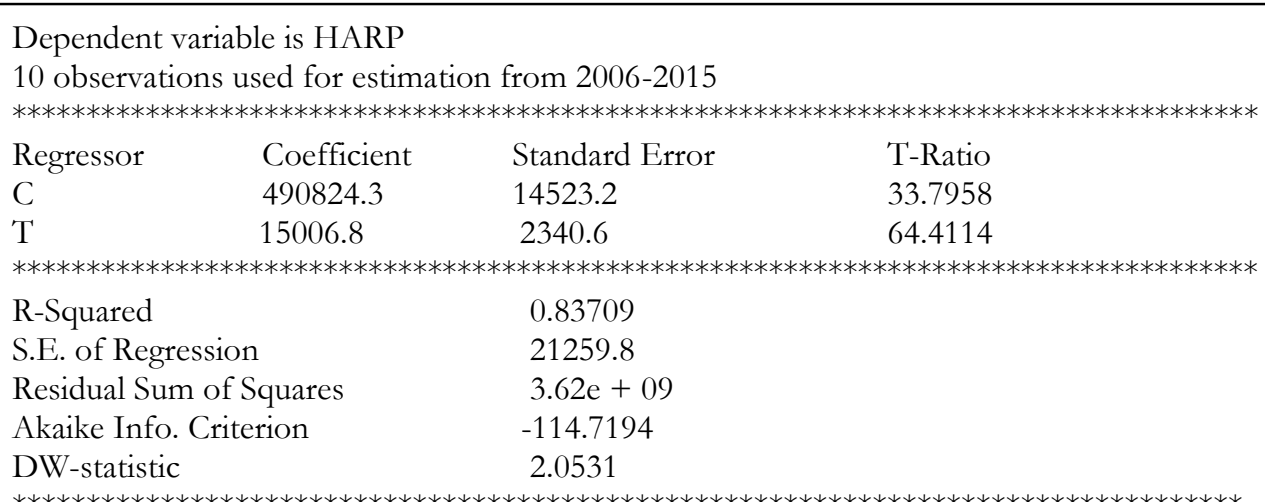

Table 8. Predicting Quantity of Produced Malt for the next ten years

\begin{tabular}{|c|c|c|c|}
\hline \multicolumn{4}{|c|}{$\begin{array}{l}10 \text { observations used for estimation from } 2006-2015 \\
* * * * * * * * * * * * * * * * * * * * * * * * * * * * * * * * * * * * * * * * * * * * * * * * * * * * * * * * * * * * * * * * * * * * * * * * * * * *\end{array}$} \\
\hline Regressor & Coefficient & Standard Error & T-Ratio \\
\hline $\mathrm{C}$ & 411042.7 & 29302.2 & 14.0277 \\
\hline $\mathrm{T}$ & 27609.0 & 4722.5 & 5.8463 \\
\hline \multicolumn{4}{|c|}{ 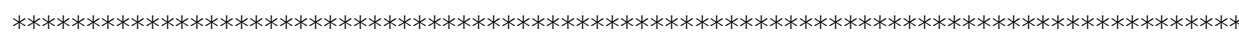 } \\
\hline \multicolumn{4}{|c|}{ R-Squared $\quad 0.81033$} \\
\hline \multicolumn{2}{|c|}{ S.E. of Regression } & 42894.0 & \\
\hline \multicolumn{2}{|c|}{ Residual Sum of Squares } & $1.47 \mathrm{e}+10$ & \\
\hline \multicolumn{2}{|c|}{ Akaike Info. Criterion } & -121.7385 & \\
\hline \multicolumn{2}{|c|}{ DW-statistic } & 2.10102 & \\
\hline
\end{tabular}


Table 9. Estimated Quantity of Produced Stout, Harp and Malt for the next ten years

\begin{tabular}{|c|c|c|c|c|}
\hline \multirow{2}{*}{ S/N } & \multirow{2}{*}{ Year } & \multicolumn{3}{|c|}{ Estimated quantity produced (litres) } \\
\cline { 3 - 5 } & & Stout & Harp & Malt \\
\hline$F_{1}\left(\mathrm{y}_{11}\right)$ & 2016 & 809120.2 & 644899.1 & 714741.7 \\
\hline $\mathrm{F}_{2}\left(\mathrm{y}_{12}\right)$ & 2017 & 832361.1 & 670905.9 & 742350.7 \\
\hline $\mathrm{F}_{3}\left(\mathrm{y}_{13}\right)$ & 2018 & 855602 & 685912.7 & 762350.7 \\
\hline $\mathrm{F}_{4}\left(\mathrm{y}_{14}\right)$ & 2019 & 878842.9 & 700919.5 & 797568.7 \\
\hline $\mathrm{F}_{5}\left(\mathrm{y}_{15}\right)$ & 2020 & 902083.8 & 715926.3 & 825177.7 \\
\hline $\mathrm{F}_{6}\left(\mathrm{y}_{16}\right)$ & 2021 & 925324.7 & 730933.1 & 852786.7 \\
\hline $\mathrm{F}_{7}\left(\mathrm{y}_{17}\right)$ & 2022 & 948565.6 & $745939.3-$ & 880395.7 \\
\hline $\mathrm{F}_{8}\left(\mathrm{y}_{18}\right)$ & 2023 & 971806.5 & 760946.7 & $908004.7-$ \\
\hline $\mathrm{F}_{9}\left(\mathrm{y}_{19}\right)$ & 2024 & 995047.4 & 775953.5 & 935613.7 \\
\hline $\mathrm{F}_{10}\left(\mathrm{y}_{20}\right)$ & 2025 & 1018288.3 & 790960.3 & 963222.7 \\
\hline
\end{tabular}

Table 9 shows that there is an increase in the quantity of stout, harp and malt products produced. This is an indication that there is a great potential for the expansion of stout production. The potential expansion in the product production is driven by sustained demand for the product.

\section{Conclusion}

In an attempt to determine the profitability and viability of brewing production in Guinness Nigeria Limited, Edo state, in view of establishing the prospects of the Nigeria brewery industry, the following observations and findings were noted: that Guinness products production is influenced by demand, inflation and exchange rate. Analysis of data further showed that the $\mathrm{R}^{2}$ value for Stout is 0.99349 , harp is 0.90981 and 0.99498 for malt, which are statistically significant, indicating that there is a strong relationship between the explanatory variable and the dependent variable. The results of multiple regression showed that demand, inflation and exchange rate were significant determinants of Guinness products production output, an indication that there is a direct and significant relationship between inflation, exchange rate and the adjusted market value for inflation in Nigeria manufacturing sector. It further showed that demand is higher, which indicates that it is the main dependent variable in the level of product production. The observed Dublin Watson Statistics were 2.0921, 2.0411 and 2.335 respectively, an indication that they are reliable. Results showed that the future is bright for Guinness Nigeria Limited, Benin, because of the sustained demand for its products and projections for Guinness products showed an increasing trend up to 2025, suggesting again a positive future for the brewery industry in Nigeria. However, demand and inflation are some of the factors limiting product production in the company. In conclusion, it can be said that given the current production technology employed by the company, brewing production is both profitable and viable. If the technology is improved upon, it is believed that profitability and viability of the brewery industry will be greatly improved.

\section{Conflict of Interests}

Authors declare that there is no conflict of interests associated with this research.

\section{References}

Kayode, M. O. (2009). Marketing management: Analyses, planning, implementation and control. New-Delhi: Prentice hall Ola, B. (2011), Advertising exposure, loyalty and brand purchase. A two stage model for choice, Journal of marketing research, 5(8), 134-144.

Central Bank of Nigeria, (2003). Annual report on structural adjustment program

Koutsoyiannis, A. (1977). Theory of Econometrics, an introduction, exposition of economics method, London, the Macmillan press Ltd ( $2^{\text {nd }}$ ed), $59-72$.

Mirsky, S. (2007). Ale's Well with the World. Scientific American. https://www.scientificamerican.com/article/ales-well-with-theworld/, retrieved on 4 November 2007.

Max, N. (2005). The barbarian's beverage: a history of beer in ancient Europe. London: Routledge OCLC 58387214. https://en.wikipedia.org/wiki/Special:BookSources/978-0-415-31121-2

Ted, G. (2008). The Brewer's Handbook: The Complete Book to Brewing Beer (2nd Ed.), Apex.

Chris, B. (2013). Encyclopedia of Brewing, John Wiley \& Sons, page 236.

Evans, E. (2011). The Oxford Companion to Beer, Oxford University Press.

Yin, X. (2003). Advertising and entering deterrence: An exploratory model. Journal of Political economy, 91(4): 636-653.

Louis, F. H., \& Oppenheim, A. L. (2001). On Beer and Brewing Techniques in Ancient Mesopotamia. Supplement to the Journal of the American Oriental Society. 
Ugboya \& Odiamenhi/Journal of Advances in Science and Engineering. Volume 2 Number 1 (2019): 17-24

Equity Research Report (2006). Meristen Securities Limited NB 12 - Month Price/Volume Chart. www.meristering.com; retrieved on $4^{\text {th }}$ January, 2011 